\title{
均一沈澱法によるアルミナ水和物ゲルの合成
}

\author{
藤田一美・松田恵三・香山勲 \\ (東海大学 理学部 化学科)
}

\section{Synthesis of Hydrated Alumina Gel by the Homogeneous Precipitation Method}

By

Kazumi FUJITA, Keizo MATSUDA and Isao KAYAMA

(Dept. of Chemistry, Faculty of Science, Tokai Univ. Hiratsuka, Kanagawa)

\begin{abstract}
Hydrated alumina gel was synthesized by the homogeneous precipitation method from urea and aluminum salts, and the influence of anions in the aqueous solutions on the hydrated alumina gel was investigated by the continuous measurement of $\mathrm{pH}$, the powder $\mathrm{X}$-ray diffraction analysis and the microscopic observation.

When an aluminum sulfate was used, a superior filterable granular substance was obtained. On the other hand when an aluminum chloride or an aluminum nitrate was used, an inferior filterable gel-like substance was obtained, and the $\mathrm{pH}$ value of the precipitation obtained was about 4 in the former case and about 7 in the latter.

These products were confirmed by the microscopic observation that the granular substance has a globular form, while the gel-like substance was an indefinite form. Both gel-like and granular substance were amorphous according to the $\mathrm{X}$-ray diffraction analysis.

From these results it was made clear that the hydrated alumina gels synthesized by the homogeneous precipitation method have different properties depending on the starting materials.
\end{abstract}

[Received May 29, 1975]

\section{1. 緒訔}

アルミノゲルの合成は従来アルミン酸アルカリと 酸, アルミニウム塩とアルカリなど多数報告されてい $る^{1) \sim 14)}$. いままでの方法では沈澱剤の添加時において溶 液内で部分的に濃度, $\mathrm{pH}$ 值, 温度などの不均一化が起 こり，そこに生成する沈濒物の性状に相違が生じ均質な 沈澱物を再現性良く得ることは極めて困難であるといわ れている ${ }^{15), 16)}$ ，つねに一定の組成および物性を有する 無定形アルミナ水和物を再現性良く得るためにはいわゆ

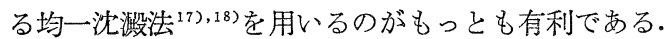

従来均一沈澱法は目的とする元素を定量的に沈澱させ ること, 㴛密な沈澱をつくること, 共沈澱により污染さ れない物質をつくることなどを目的とし重量分析の一手 段として使用されている. 本研究は従来の不均一沈測法

(アルミン酸アルカリ溶液に酸を，アルミニウム塩溶液 にアルカリ溶液を加える方法）と異なり尿素を使用する 均一沈澱法（アルミニウム塩溶液に加熱によって加水分 解する尿素をあらかじめ溶解し均一溶液としたのちに加
熱を行い，加熱によってアンモニアが発生するので溶液 の $\mathrm{pH}$ を均一に徐々に上げてゆく方法）をアルミナ水 和物ゲルの合成の目的に使用し，合成のさいの出発物質 （塩化アルミニウム, 硫酸アルミニウム, 硝酸アルミニ ウム）の影響家報告する.

\section{2. 実験}

\section{1 アルミナ水和物ゲルの合成}

2.1 .1 塩化アルミニウムと尿素との反応塩化ア ルミニウム 6 水和物 $10 \mathrm{~g}$ に尿素 $10.8 \mathrm{~g}$ を溶解してい る混合水溶液 $200 \mathrm{ml}$ を $95 \sim 97^{\circ} \mathrm{C}$ の蒸気浴内で 1 時間 30分加熱処理を行って沈澱をつくり，その沈澱を十分水 洗し $110^{\circ} \mathrm{C}$ 乾燥を行った.

2.1 .2 硫酸アルミニウムと尿素との反応硫酸ア ルミニウム $16 \sim 18$ 水和物 $13.3 \mathrm{~g}$ に尿素 $10.8 \mathrm{~g}$ を同 様な方法により 2 時間加熱処理を行い，その沈澱を 2.8 \%アンモニア水で洗浄後十分水洗し室温で真空乾燥を行 った. 
31 藤田一美ほか

2.1.3 硝酸アルミニウムと尿素との反応硝酸ア ルミニウム 9 水和物 $15 \mathrm{~g}$ に尿素 $10.8 \mathrm{~g}$ を塩化アルミ ニウムの場合と同様な方法により処理した.

\section{$2.2 \mathrm{pH}$ の連続測定}

高温用ガラス電極，高温用比較電極，高温用自動温度 補償電極を入れた混合水溶液を $95 \sim 97^{\circ} \mathrm{C}$ 蒸気浴内に入 れ日立堀場製 $\mathrm{M} 5$ 型 $\mathrm{pH}$ 計に万能記録計を接続し $\mathrm{pH}$ の変化を連続的に測定記録した.

\section{$2.3 \mathrm{X}$ 線回折}

$\mathrm{X}$ 線回折は理学電機製 $\mathrm{X}$ 線回折装置で $\mathrm{CuK}_{\alpha}$ 線を用 い( $\mathrm{Ni}$ フィルター) $10 \sim 70^{\circ}(2 \theta)$ を $2^{\circ} / \mathrm{min} て ゙$ 走 查した.

\section{4 顕微鏡観察}

顕微鏡観察はオリンパス MFTR 型を用いた。

\section{3. 結果亡考察}

\section{1 混合水溶液の加熱時間に対する $\mathrm{pH}$ 曲線}

アルミニウム塩と尿素との混合水溶液の加熱時間に対 する $\mathrm{pH}$ 曲線を 図-1 に示す.

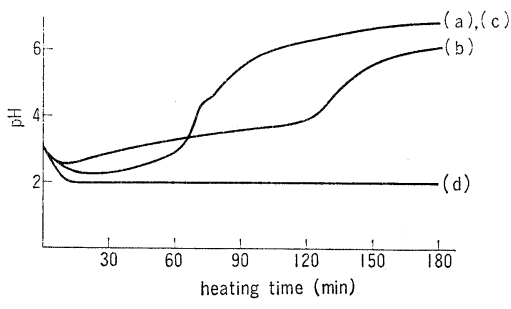

Fig. 1. Change of $\mathrm{pH}$ value with heating time.

(a) : Aluminum chloride $(0.2 \mathrm{~mol} / l)$, urea $(0.6 \mathrm{~mol} / l)$, total solution $(200 \mathrm{~m} l)$

(b) : Aluminum sulfate $(0.1 \mathrm{~mol} / l)$, urea $(0.6 \mathrm{~mol} / l)$, total solution $(200 \mathrm{~m} l)$

(c) : Aluminum nitrate $(0.2 \mathrm{~mol} / l)$, urea $(0.6 \mathrm{~mol} / l)$, total solution $(200 \mathrm{~m} l)$

(d) : Aluminum chloride $(0.2 \mathrm{~mol} / l)$, total solution $(200 \mathrm{~m} l)$

図-1 の $\mathrm{pH}$ 曲線（a)，(b)，(c) の形から $\mathrm{pH}$ 值の 下降，ゆるやかな上昇，ほぼ一定，上昇の 4 つにくぎる ことができる. $\mathrm{pH}$ 值の下降は反応器内に混合水溶液を 大れてもすぐに混合水溶液の温度が反応器内の温度と等 しくならず徐々に混合水溶液の温度が上昇するためであ る.このことは (d) よりあきらかである. $\mathrm{pH}$ 值の下降 の原因が混合水溶液の温度上昇にあるから (a), (b), (c)，(d) とも同じ $\mathrm{pH}$ 值を示すはずであるが，加熱時 間が 10 分のとき，(a), (b), (c) の $\mathrm{pH}$ 值が約 2.5, （d） は約 2 である.この $\mathrm{pH}$ 值の差の原因は溶解して いる尿素の一部が混合水溶液の温度上昇にともなって加 水分解を起こしたためであろら. $\mathrm{pH}$ 值のゆるやかな上 昇を解明するために以下の実験を行った. 塩化アルミニ ウム水溶液に塩酸, 硫酸アルミニウム水溶液に硫酸を加 えて $\mathrm{pH}$ 值を 3 に調節したの ち, アンモニア水を滴下
窝業協会誌 83 [12] $1975 \quad 587$

し $\mathrm{pH}$ 值を測定した. 次に塩化アンモニウム水溶液, 硫酸アンモニウム水溶液, それぞれと尿素の混合水溶液 を同様な方法により $\mathrm{pH}$ 值を 3 にし 95 9 ${ }^{\circ} \mathrm{C}$ の蒸気 浴内で反応させ $\mathrm{pH}$ 值を測定した. その結果を図-2 に 示す. 図-2(A) の (a), (b) とも120分までの $\mathrm{pH}$ 值が ほぼ同じであること，(B) の（a） は急激な $\mathrm{pH}$ 值の上 昇を示し，(b) はなだらかな上昇走すことより 図-1 (a)，(b)，(c) ともゅるやかな $\mathrm{pH}$ 值の上昇は共存する アルミニウムイオン, 塩化物イオン, 硫酸イオン, 硝酸 イオンなどの緩衝作用的な影響を受けて尿素の加水分解 により生成したアンモニアによって上昇すべき $\mathrm{pH}$ 值 が抑制されるためであるう。 $\mathrm{pH}$ 值がほぼ一定值をとる のは，この亡きき沈搌生成が認められることより，その間 中沈澱の生成が行われていると見なすことができよう。 それ以後の $\mathrm{pH}$ 值の上昇は尿素の加水分解によって生 成したアンモニアによるためであろう. 図-1 の (a), (b), (c) の相違点は (a), (c) は急激な $\mathrm{pH}$ 值の上昇 後に沈澱生成が開始する点，(b) はそのような急激な $\mathrm{pH}$ 值の上昇が認められず，かつ沈搌生成の $\mathrm{pH}$ 值が (a)，(c) 注約 7, (b) अ約 4 （室温で $\mathrm{pH}$ 值を測定） などである。

(A)

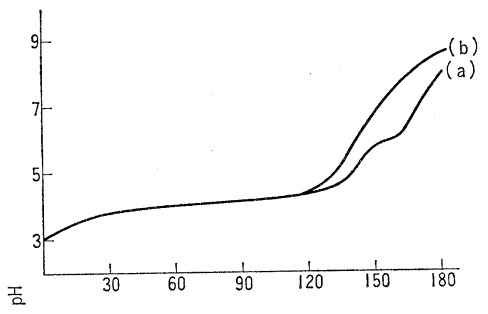

(B)

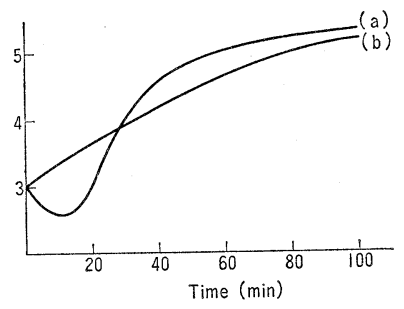

Fig. 2. Change of $\mathrm{pH}$ value with time.

$\mathrm{A}:$ Rate of the addition of ammonia solution $(0.2 \%): 0.07$ $\mathrm{m} l / \mathrm{sec}$

(a) : Aluminum chloride $(0.2 \mathrm{~mol} / l)$, total solution $(200 \mathrm{~m} l)$

(b) : Aluminum sulfate $(0.1 \mathrm{~mol} / l)$, total solution $(200 \mathrm{~m} l)$

$\mathrm{B}:$ (a) : Ammonium chloride $(0.1 \mathrm{~mol} / l)$, urea $(0.05 \mathrm{~mol} / l)$, total solution $(200 \mathrm{~m} l)$

(b) : Ammonium sulfate $(0.05 \mathrm{~mol} / l)$, urea $(0.05 \mathrm{~mol} l)$, total solution $(200 \mathrm{~m} l)$

以上の相違は溶液中でアルミニウムイオンがどのよう な形で存在しているかによると思われるが，直接溶液中 のアルミニウムイオンの構造を測定することは非常に困 難であるが，ラマン吸収の手段を用いてある程度知るこ とができ ${ }^{19)}$, 溶液中のアルミニウムは $\mathrm{Al}_{4}(\mathrm{OH})_{8}{ }^{4+}, \mathrm{Al}_{6}$ $(\mathrm{OH})_{15}{ }^{3+}$ のような複合イオンの形で溶けていると考え 


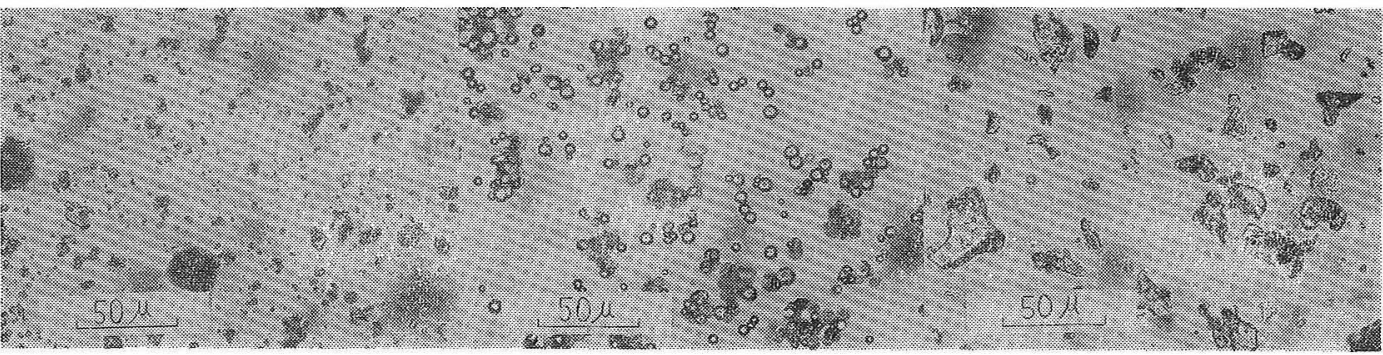

(a)

(b)

(c)

Fig. 3. Microphotographs for the hydrated alumina gels by the homogeneous precipitation method.

(a) : Precipitated from urea and aluminum chloride

(b) : Precipitated from urea and aluminum sulfate

(c) : Precipitated from urea and aluminum nitrate

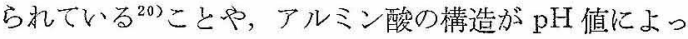
て変化する ${ }^{21)}$ とれていることからこのような形の褀合 イオンが溶液内に存在するであるう。そして共存する陰 イオンと結合して生ずる複合イオンの状態の変化はアル

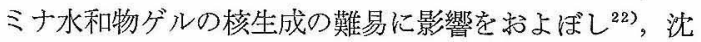
洉生成時の $\mathrm{pH}$ 值が異なったり加熱時間に﨎する $\mathrm{pH}$ 曲線が異なるのはあきらかであらう。

\section{2 アルミナ水和物ゲルのX線回新と顕微鏡観察}

アルミノゲルを乾燥するとベーマイトゲルに変化する と報告されている ことより，均一沈測法での合成物の X線回折を試みた。その結果, 塩化物, 硫酸塩, 硝酸塩 より合成したアルミナ水和物ゲルはすべて回折図形を示 さず無定形で少り差異は認められなかった。また図ー30 顕微鏡写真より塩化物，硝酸篮からの合成物とも形が一 定していないのに対し，硫酸塩加らの合成物は球形を示 した、このことより合成物はX線回折图形より同一であ ると思われる．出発物質の相違によってゲル状物質や粒 子状物質が生成するが，粒子状態の差異の原因について は今後改めて検討したい。

\section{4. 総括}

尿素とアルミニウム塩類による均一沈澱法を用いてア ルミナ水和物ゲル定成し，合成のさいの陻イオンの影 響を $\mathrm{pH}$ の連続測定，粉末X線回行，顕微鏡観察など から検討した。

アルミナ水和物ゲルを合成する場合, 塩化アルミニウ ムや硝酸アルミニウムを用いると，万過性の悪いゲル状 物質，硫酸アルミニウムを用いると，ろ過性の良い粒子 状物質が得られ，ゲル状物質が約 7，粒子状物翼が約 4 の $\mathrm{pH}$ で沈測した。これら合成物の顥微鏡観察よりゲル 状物質は不定形を示し，粒子状物翼は球形を示したがX 線回折の結果は共に回折図形を示さず無定形であった。

以上の結果より均一沈洪法を用いて合成したアルミナ 水和物ゲルは出発物質の相違によってその性状が異な る.これは溶液中のイオン精造が異なるという仮説を使
えば説明できる。

なお，本研究にあたり，有益なる御助言をいただいた横兵国 立大学鳥屋泰男助教授に深く感謝致します。

\section{文献}

1) 乎不好右衛門, 清水義勝, 電気化学 28, 302-12 (1960)。

2）舟木好右街門，清水義勝，電気化学 28, 358-64 (1960).

3) 坂本憲一, 窒協 67 [4] C 114-25 (1959).

4) J.A. Lewis, C.A. Taylor, J. Appl. Chem. 8 [4] 223-28 (1958).

5) H. Sonntag, K. Rödel, Z. Anorg. Allgem. Chem. 343, 131-38 (1966).

6) T. Sato, T. Yamashita, F. Ozawa, Z. Anorg. Allgem. Chem. 370, 202-08 (1969).

7) H. Ginsberg, W. Hüttig, H. Stiehl, Z. Anorg. Allgem. Chem. 309 [4] 233-44 (1961).

8) H. Ginsberg, W. Hüttig, H. Stieh1, Z. Anorg. Allgem. Chem. 318, 238-56 (1962).

9) B.P. Gyani, J. Phys. Chem. 56 [6] 762-63 (1952).

10）山田谷正子, 木下 武, 下村饮也, 内田 熙, 工化 73 [5] 847-51 (1970).

11）山田谷正子, 木下 武, 下村欣也, 内田 熙, 工化 72 [5] 1050-55 (1969).

12) G. Yamaguchi, W.C. Chiu, Bull. Chem. Soc. Ja. pan. 41 [2] 348-53 (1968).

13) D. Aldrroft, G.C. Bye, J.G. Robinson, K.S.W. Sing, J. Appl. Chem. 18 [10] 301-06 (1968).

14）久保輝一郎，内田 清。工化 73 [1] 70-75 (1970).

15）清水義勝, 宮重 敏, 揞木好右衛門, 工化 67 [5] 78897 (1964).

16）清水准勝, 石島 格, 桌木好右衛門, 工化 87 [8] 118790 (1964).

17）日本化学会編，“実験化学講座，絸 2”，丸善 (1967) p. 179-81.

18) H.H. Willard, N.K. Tang, J. Am. Chem. Soc. 59, 1190 (1937).

19) L.A.Carreira, V.A. Maroni, T.W. Swaine, Jr., R.C Plub, J. Chem. Phys. 45 [6] 2216-20 (1966).

20) J.J. Fripiat, F. Van Cauwelaert, H. Bosmans, J. Phys. Chem. 69 [7] 2458-61 (1965).

21) I. Gallily, S.K. Friedlander, J. Chem. Phys. 42 1503 (1965).

22）小野修一郎，山口悟郎，柳田博明，湾水紀夫，悹協 76 [7] 207-18 (1968).

(5/29/1975 受付) 